\title{
Outbreaks of Chrysodeixis includens (Walker) (Lepidoptera: Noctuidae) in common bean and castor bean in São Paulo State, Brazil
}

\author{
Edson Luiz Lopes Baldin ('); André Luiz Lourenção (2*); Eunice Cláudia Schlick-Souza (') \\ (') Universidade Estadual Paulista (UNESP), Faculdade de Ciências Agronômicas (FCA), Departamento de Proteção Vegetal, Rua José \\ Barbosa de Barros, 1780, 18610-307 Botucatu (SP), Brasil. \\ (2) Instituto Agronômico (IAC), Centro de Fitossanidade, Av. Barão de Itapura, 1481, 13020-902 Campinas (SP), Brasil. \\ $\left({ }^{*}\right)$ Corresponding author: andre@iac.sp.gov.br
}

Received: Aug. 22, 2014; Accepted: Sept. 11, 2014

\begin{abstract}
Since 2009, increasing populations of Chrysodeixis includens (Walker) (Lepidoptera: Noctuidae) have been observed in cultivated common bean (Phaseolus vulgaris L.) and castor bean (Ricinus communis L.) at the Lageado Experimental Farm, belonging to the FCA/UNESP, Botucatu, São Paulo State, Brazil. Defoliations around 80\% and 50\% were observed in the common bean cv. Pérola and castor bean Cv. IAC-2028, respectively. Samples of individuals (caterpillars and pupae) were collected in the field, and kept in laboratory until adult emergence aiming to confirm the species. These are new observations for common bean in São Paulo State and, in the case of castor bean, unpublished in Brazil. It suggests that C. includens has adapted to attack other agricultural crops, demanding attention of common bean and castor bean producers.
\end{abstract}

Key words: herbivory, alternative hosts, soybean looper.

\section{Surtos populacionais de Chrysodeixis includens (Walker) (Lepidoptera: Noctuidae) em feijoeiro e mamoneira no Estado de São Paulo, Brasil}

\begin{abstract}
Resumo
Desde 2009, populações crescentes de Chrysodeixis includens (Walker) (Lepidoptera: Noctuidae) vêm sendo observadas em lavouras de feijoeiro comum (Phaseolus vulgaris L.) e mamoneira (Ricinus communis L.), na Fazenda Experimental Lageado, pertencente à FCA/UNESP, Campus de Botucatu, Estado de São Paulo, Brasil. Desfolhas ao redor de 80\% e 50\% foram constatadas em feijoeiro Pérola e em mamoneira IAC-2028, respectivamente. Amostras de indivíduos (lagartas e pupas) foram coletadas a campo e mantidas em laboratório até a emergência dos adultos para confirmação da espécie. Essas observações em feijoeiro são inéditas para o estado de São Paulo e, no caso da mamoneira, inéditas no Brasil, sugerindo que o inseto vem se adaptando e atacando outras culturas de interesse agrícola, exigindo maior atenção por parte dos produtores de feijão e mamona.
\end{abstract}

Palavras-chave: herbivoria, hospedeiros alternativos, lagarta falsa-medideira.

Common bean (Phaseolus vulgaris L.) has great importance in the Brazilian socio-economic context (Cabral et al., 2011). The plant is native to Latin America and currently is cultivated worldwide. Brazil is the largest producer of this grain, followed by India, China, Mexico and USA. This huge production is a result of cultivation from north to south, almost year around, being able to yield up to three harvests a year (EMBRAPA, 2003). Being Brazil an important producer of common bean, the attack of several insect pests that may compromise the yield deserves special attention (Vieira et al., 2006).

The castor bean (Ricinus communis L.) is indigenous to the African continent, where six subspecies occurs. Dozens of cultivars and hybrids are commercially grown worldwide (Savy Filho et al., 1999). Castor beans are highly adapted to Brazil (Corrêa et al., 2006; Costa et al., 2009), where increasing interest exists due to the versatility of the oil extracted from the seeds recently used also in the composition of biodiesel (Maciel et al., 2007; Oliveira, 2011). Despite its significative overall production, the Brazilian productivity is considered low compared to the ones of other countries (CONAB, 2011). This situation may in part be associated to attack of pests (Ribeiro and Costa, 2008; Savy Filho et al., 1999).

Although the soybean looper Chrysodeixis includens (Walker) (Lepidoptera: Noctuidae) is a polyphagous pest for several countries (Herzog, 1980; Sinclair et al., 1997), in Brazil the species was considered for many decades a minor pest of soybean (Moscardi et al., 2012). However, excessive fungicide application (Sosa-Gómez, 2013), 
associated to the use of mixtures of pesticides has reduced the population of natural enemies of this insect (EMBRAPA, 2009; Moscardi, 2009), favoring its spread within crops and migration to other cultures (EMBRAPA, 2009). In common bean, $C$. includens has growing importance in some states such as Goiás and Paraná (Chiaradia, 2013; Quintela, 2009), due to the damage caused in recent seasons. However, to date, there are no reports of this pest causing damage to castor bean in Brazil. In this crop, records of defoliating pests include various species of caterpillars (Batista et al., 1996; Gallo et al., 2002; Lourenção et al., 1989; 1996), but none of them refers to $C$. includens. Generally, insect attack causes characteristic damages on the leaf surface of plants, especially in the more developed leaves. Moreover, the caterpillar does not feed on the veins of the leaves, which show lacy appearance (Bueno et al., 2011; Herzog, 1980).
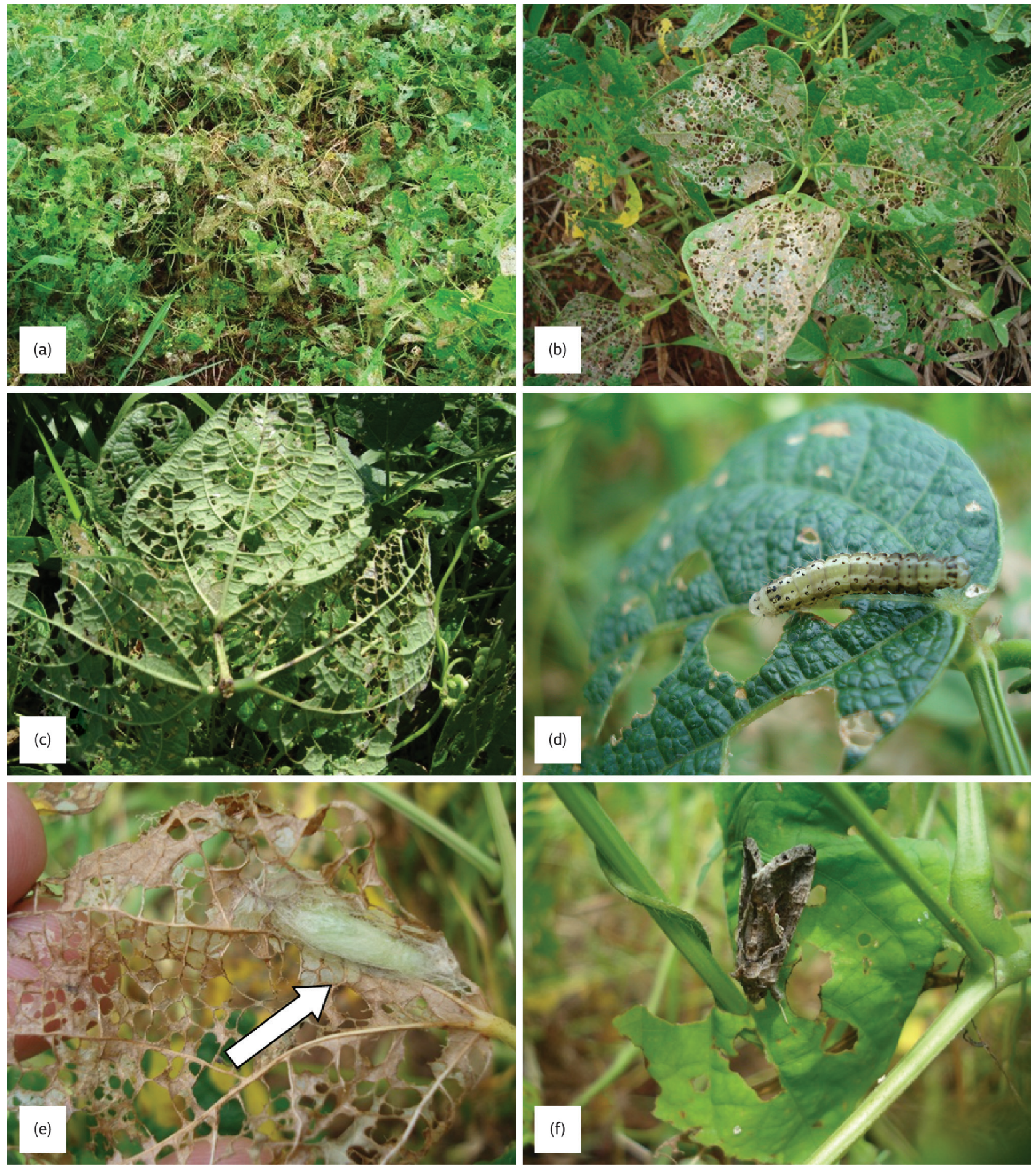

Figure 1. Defoliation on common bean plants (a-c) and different phases (d-f) of Chrysodeixis includens. 

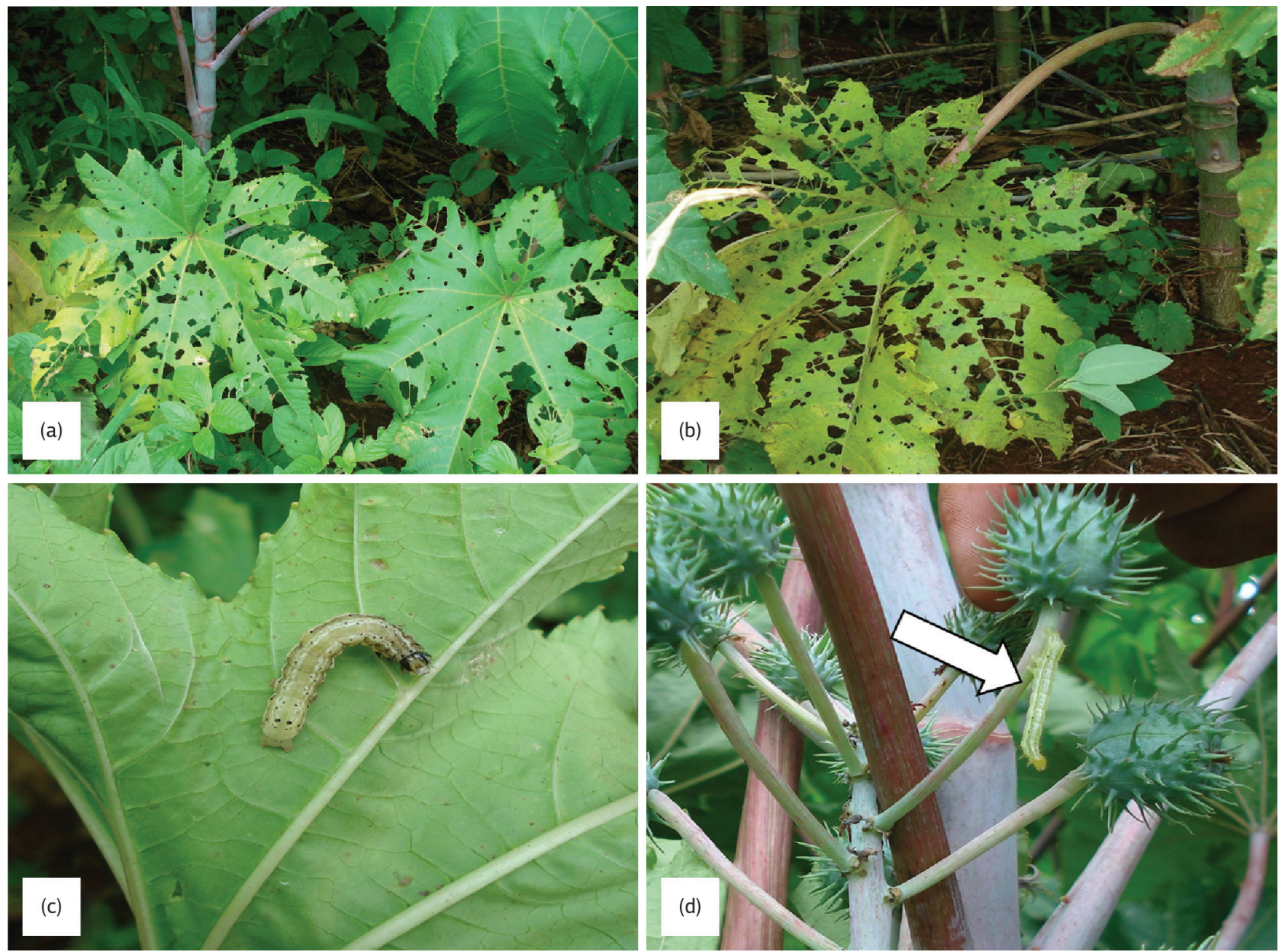

Figure 2. Defoliation on castor bean plants (a-b) and caterpillars (c-d) of Chrysodeixis includens.

From 2009, increasing populations of $C$. includens have been observed in areas cultivated with common bean (cv. Pérola) and castor bean (cv. IAC-2028) at the Lageado Experimental Farm (22 $\left.51^{\prime} \mathrm{S}, 48^{\circ} 26^{\prime} \mathrm{W} 740 \mathrm{~m}\right)$ belonging to FCA/UNESP, Botucatu (SP). Defoliation around to $80 \%$ was observed in infested plants of common bean (Figure 1a). The lacy appearance (preserved veins), similar to that reported for soybean (Sullivan and Boethel, 1994) was also found on the leaves of damaged plants (Figure 1b,c). Characteristic soybean loopers, pupae (edges of the leaves) and adults were also observed in several structures of plants (Figure 1d-f). Infested castor bean plants showed different levels of defoliation, reaching $50 \%$ in some plants (Figure 2a,b). Numerous caterpillars were found on leaves and reproductive structures of plants (Figure 2c,d).

Samples (caterpillars and pupae) were collected from both cultures and kept under laboratory conditions $\left(25 \pm 2{ }^{\circ} \mathrm{C}\right.$, $\mathrm{RH}=70 \pm 10 \%$ and photoperiod $=12 \mathrm{~h}$ ) until adult emergence. Subsequently, identification of species was confirmed by Prof. Dr. Sinval Silveira Neto (ESALQ/USP).

The levels of defoliation occurring in both crops have reduced yields in recent seasons, indicating the need of more attention of the producers and the adoption of control strategies. The presence of different cycle phases of the insect for both cultures suggests that this pest is adapted to colonize these crops. This is the first record of $C$. includens attacking castor bean in Brazil and the common bean in São Paulo State.

\section{ACKNOWLEDGEMENTS}

The authors thank CNPq, CAPES, and FAPESP for financial support and scholarships provided for this research. We also thank to Prof. Dr. Sinval Silveira Neto for identifying Chrysodeixis includens.

\section{REFERENCES}

BATISTA, F.A.S.; LIMA, E.F.; SOARES, J.J.; AZEVEDO, D.M.P. Doenças e pragas da mamoneira (Ricinus communis L.) e seu controle. Campina Grande: EMBRAPA-CNPA, 1996. 53p. (Circular Técnica, 21)

BUENO, R.C.O.F.; BUENO, A.F.; MOSCARDI, F.; PARRA, J.R.P.; HOFFMANN-CAMPO, C.B. Lepidopteran larvae consumption 
of soybean foliage: basis for developing multiple-species economic thresholds for pest management decisions. Pest Management Science, v.67, p.170-174, 2011. PMid:20981726. http://dx.doi.org/10.1002/ ps.2047

CABRAL, P.D.S.; SOARES, T.C.B.; LIMA, A.B.P.; SOARES, Y.J.B.; SILVA, J.A. Análise de trilha do rendimento de grãos de feijoeiro (Phaseolus vulgaris L.) e seus componentes. Revista Ciência Agronômica, v.42, p.132-138, 2011. http://dx.doi.org/10.1590/ S1806-66902011000100017

CHIARADIA, L.A. Manejo integrado de pragas na cultura do feijão. In: WORDELL FILHO, J.A.; CHIARADIA, L.A.; BALBINOT, A. (Eds.). Manejo fitossanitário na cultura do feijão. Florianópolis: Epagri, 2013. p.73-103.

COMPANHIA NACIONAL DE ABASTECIMENTO - CONAB. Mamona Brasil - série histórica de área plantada - Safras 1976/77 a 2009/10. Brasília. Disponível em: <http://www.conab.gov.br/conabweb/ download/safra/MamonaSerieHist.xls>. Acesso em: 5 ago. 2011.

CORRÊA, M.L.P.; TÁVORA, F.J.A.F.; PITOMPEIRA, J.B. Comportamento de cultivares de mamona em plantio consorciadas com caupi e sorgo granífero. Revista Ciência Agronômica, v.37, p.200-207, 2006.

COSTA, F.X.; BELTRÃO, N.E.M.; LIMA, V.L.A.; NUNES JÚNIOR, E.S.; GUIMARÁES, M.M.B.; DAMACENO, F.A.V. Efeito do lixo orgânico e torta de mamona nas características de crescimento da mamoneira (Ricinus communis L.). Revista Engenharia Ambiental, v.6, p.259-268, 2009.

EMPRESA BRASILEIRA DE PESQUISA AGROPECUÁRIA - EMBRAPA. Cultivo do feijoeiro comum. Santo Antônio de Goiás: Embrapa Arroz e Feijão, 2003. (Sistemas de Produçáo, 2). Disponível em: <http://sistemasdeproducao.cnptia. embrapa.br/FontesHTML/Feijao/CultivodoFeijoeiro/expediente.htm>.

EMPRESA BRASILEIRA DE PESQUISA AGROPECUÁRIA - EMBRAPA. Ata da XXX Reunião de Pesquisa de Soja da Região Central do Brasil. Londrina: Embrapa Soja, 2009. 350p. (Documentos, 310)

GALLO, D.; NAKANO, O.; SILVEIRA NETO, S.; CARVALHO, R.P.L.; BAPTISTA, G.C.; BERTI FILHO, E.; PARRA, J.R.P.; ZUCCHI, R.A.; ALVES, S.B.; VENDRAMIM, J.D.; MARCHINI, L.C.; LOPES, J.R.S.; OMOTO, C. Entomologia agrícola. Piracicaba: FEALQ, 2002. 920p.

HERZOG, D.C. Sampling soybean looper on soybean. In: KOGAN, M.; HERZOG, D.C. (Ed.). Sampling methods in soybean entomology. New York: Springer-Verlag, 1980. p.140-168. http://dx.doi. org/10.1007/978-1-4612-9998-1_7

LOURENÇÃO, A.L.; CARVALHO, L.O.; LASCA, D.H. Anacraga citrinopsis Dyar (Lepidoptera: Dalceridae) em mamoneira no estado de São Paulo. Bragantia, v.48, p.109-112, 1989. http://dx.doi. org/10.1590/S0006-87051989000100010
LOURENÇÃO, A.L.; SAVY FILHO, A.; BANZATO, N.V.; PAULO, E.M. Insetos e ácaros associados à mamoneira no Brasil. Campinas: Instituto Agronômico, 1996. 10p. (Boletim Técnico, 157)

MACIEL, C.D.G.; POLETINE, J.P.P.; VELINI, E.D.; ZANOTTO, M.D.; AMARAL, J.G.C.; SANTOS, H.R.; ARTIOLI, J.C.; SILVA, T.R.M.; FERREIRA, R.V.; LOLLI, J.; RAIMONDI, M.A. Seletividade de herbicidas em cultivares de mamona. Revista Brasileira de Oleaginosas e Fibrosas, v.11, p.47-54, 2007.

MOSCARDI, F. Problemática das populaçôes de insetos em desequilíbrio e a retomada do Manejo Integrado de Pragas (MIP). In: SARAIVA, O.F.; LEITE, R.M.V.B.C.; CASTRO, C. Ata da XXX reunião de pesquisa de soja da Regiāo Central do Brasil. Londrina: Embrapa Soja, 2009. 350p. (Documentos, 310)

MOSCARDI, F.; BUENO, A.F.; SOSA-GÓMEZ, D.R.; ROGGIA, S.; HOFFMAN-CAMPO, C.B.; POMARI, A.F.; CORSO, I.V.; YANO, S.A.C. Artrópodes que atacam as folhas da soja. In: HOFFMANCAMPO, C.B.; CORRÊA-FERREIRA, B.S.; MOSCARDI, F. (Ed.). Soja: manejo integrado de insetos e outros artrópodes-praga. Brasília: Embrapa, 2012. p.213-309.

OLIVEIRA, E.M. Avaliação do teor de óleo e peso em sementes de mamona utilizando diversos acessos. Engenharia Ambiental, v.8, p.205-211, 2011.

QUINTELA, E.D. Manejo Integrado de Pragas do feijoeiro. In: KLUTHCOUSKI, J.; STONE, L.F.; AIDAR, H. (Ed.) Fundamentos para uma agricultura sustentável, com ênfase na cultura do feijoeiro. Santo Antônio de Goías: Embrapa Arroz e Feijão, 2009. p.289-308.

RIBEIRO, L.P.; COSTA, E.C. Ocorrência de Erinnyis ello e Spodoptera marima na cultura da mamona no Rio Grande do Sul. Ciência Rural, v.38, p.2351-2353, 2008. http://dx.doi.org/10.1590/S010384782008000800040

SAVY FILHO, A.; BANZATO, N.V.; BARBOZA, M.Z.; MIGUEL, A.M.R.O.; DAVI, L.O.C.; RIBEIRO, F.M. Mamona - oleaginosas no Estado de São Paulo: análise e diagnóstico. Campinas: CATI, 1999. 39p. (Documento Técnico, 107)

SINCLAIR, J.B.; KOGAN, M.; MCGLAMERY, M.D. Guidelines for the integrated pest management of soybean pests. Urbana-Champaign: National Soybean Research Laboratory, 1997. 48p.

SOSA-GÓMEZ, D.R. Seletividade de agroquímicos para fungos entomopatogênicos. Disponível em: <http://cnpso.embrapa.br/ download/artigos/seletiv_fung.pdf $>$. Acesso em: 15 nov. 2013.

SULLIVAN, M.J.; BOETHEL, D.J. Loopers. In: HIGLEY, L.G.; BOETHEL, D.J. Handbook of soybean insect pests. Lanham: The Entomological Society of America, 1994. p.68-70.

VIEIRA, C.; PAULA JÚNIOR, J.; BORÉM, A. Feijão. 2. ed. Viçosa: UFV, 2006. 600p. 